\title{
An inquiry into the blurring boundaries between professionals and paraprofessionals in Dutch courts and the public prosecution service
}

\author{
N.L. Holvast ${ }^{1 \star(D)}$ and J.M.W. Lindeman ${ }^{2}$ \\ ${ }^{1}$ Erasmus University Rotterdam, Erasmus School of Law, The Netherlands and ${ }^{2}$ Utrecht University, Utrecht School of Law, \\ The Netherlands \\ *Corresponding author. E-mail: holvast@law.eur.nl
}

\begin{abstract}
The autonomous position of legal professionals is no longer self-evident. Professionals are under increased pressure to reform. This phenomenon is not only true for legal professionals. A broader trend - which is recognised for the medical profession, academic profession and alike - is that paraprofessionals are gaining a more prominent position. In this paper, we focus on the developments in the Dutch public justice system. We conduct a case-study on the role of paraprofessionals in courts and in the public prosecution service - two understudied legal institutions in this regard. By drawing on empirical data unfolding the working routine of the judiciary and the prosecution service, we find two paradigms that define the thinking about professionalism: a traditional 'pure professional' paradigm and a new, more hybrid paradigm that includes (policy-based) managerial thinking. The latter appears to be enhanced by a New Public Management (NPM) approach within these institutions. Although we observe resistance among (para) professionals towards professional changes and ambiguity in the relationships between professionals and paraprofessionals, we also observe that managerialism has changed the work processes and the division of labour between professionals and paraprofessionals.
\end{abstract}

Keywords: professionalism; managerialism; paraprofessionals; judiciary; prosecution office

\section{Introduction}

Dutch judges and prosecutors - in the Netherlands, both appointed as 'judicial civil servants' - are traditionally portrayed as 'pure professionals', as described by Freidson (1994; 2001) and Abbott $(1988)^{1}$ : professionals who establish professional control of work and occupational protection (Noordegraaf, 2007). The adjudication of justice has long been regarded as the outcome of the labour of professional workers (judges and prosecutors). However, over the years, it is increasingly being perceived as a service provided by state institutions (the judiciary and the public prosecution service). Similar to many other professional domains (e.g. health care and education), 'managerialism' or 'New Public Management' (NPM) has had a considerable impact within the administration of justice (Noordegraaf, 2015; Langbroek and Westenberg, 2018; Visser et al., 2019). We notice that this has resulted in a shift from 'traditional' professionalism to 'new', more hybrid professionalism - which introduces NPM logics into the professionalism-paradigm (see Section 2.1).

This shift and the ensuing organisational changes challenge the traditional division of power within these professional institutions (see similarly on the medical profession Bach et al., 2008; Kirkpatrick

\footnotetext{
${ }^{1}$ The Dutch body of judges that provides the administration of justice (de Rechtspraak) is in an international context commonly referred to as 'the judiciary'. The body of public prosecutors (openbaar ministerie) is often referred to as 'the public prosecution service'.

( $)$ The Author(s), 2020. Published by Cambridge University Press. This is an Open Access article, distributed under the terms of the Creative Commons Attribution licence (http://creativecommons.org/licenses/by/4.0/), which permits unrestricted re-use, distribution, and reproduction in any medium, provided the original work is properly cited.
} 
et al., 2011). One way in which the power of professionals is challenged is by promoting stratification and by introducing different types, or levels, of professional occupations within the institutions (see Noordegraaf, 2007, pp. 762-763). These processes result in blurring boundaries between 'full' professional and varying levels of 'semi-', 'quasi-' or 'para-' professional occupations (for magistrates' assistants in the UK, see e.g. Raine and Willson, 1997; for legal practitioners, see Moorhead et al., 2003; see also Sommerlad et al., forthcoming). Although it could be argued that both 'full' and 'semi' professionals have (different) levels of professionalism, in this paper, we refer to the judges and prosecutors as 'professionals' and to all others involved - who may meet some, but not all, of the requirements to be a judge or a prosecution officer - as 'paraprofessionals'. The latter group is more diverse in nature, consisting of judicial assistants, staff lawyers and a variety of prosecution assistants.

Scholarly observations on the professional shift within the legal domain have predominantly focused on its effect on legal practitioners working at (large) law firms and not on legal professionals working within the administration of justice at state institutions. In this paper, we describe the changes within state institutions in more detail, with specific attention on the changes in the positions of paraprofessionals. We investigate how new professionalism has changed the formal position of paraprofessionals, focusing on the Dutch Judiciary and public prosecution service (PPS) as a case-study. We describe how professionals deal with the changes in what 'professionalism' entails and the consequences this has for the interaction between professionals and paraprofessionals.

\section{Theory on new professionalism and methodology}

\subsection{Professionalism and NPM}

Freidson (1970) and Abbott (1988) were among the first authors to introduce the concept of professionalism, which can be contrasted with the concepts of a free market or a bureaucratic logic of organising work. Professional occupations require specific skills and knowledge, which are achieved by both formal education and training as well as informal socialisation into the profession. Lawyers have traditionally been regarded as typical professionals. In their work, they serve public interests, but partly within a commercial setting (the latter being particularly true for legal practitioners; see also the influential work by Abel, 2003).

Recently, however, various authors have noticed a shift in the conditions under which professionals conduct their work. New organisational and managerial principles were introduced into the professions. Evetts (2011) labels this as a transformation from 'occupational' professionalism to 'organisational' or 'new' professionalism. This transformation results in 'a shift from notions of partnership, collegiality, discretion and trust to increasing levels of managerialism, bureaucracy, standardization, assessment and performance review' (Evetts, 2011, p. 406). Noordegraaf (2007) similarly refers to this new type of professionalism as 'controlled professionalism', considering that the organisations start to gain control over the professionals to some extent. In line with this reasoning, Noordegraaf (2007; 2015) also introduced the concept of 'hybrid professionalism'. In this concept, organisational and managerial requirements (such as efficiency, budget control and productivity) go together with professional standards (such as quality standards, expertise, autonomy and independence), enhancing rather than weakening each other.

Particularly focusing on the legal profession, Sommerlad (1995) too recognises that the traditional legal profession is under attack by a new paradigm of managerialism. In his inaugural lecture, Moorhead (2014) argues that the legal profession today is precarious and challenged by new legal service providers. Similarly, Kritzer (1999) recognises a movement wherein legal professionalism has changed and 'formal' professionals have lost their exclusivity. As a result, 'services previously provided only by members of formal professions can now be delivered by specialized general professionals or nonprofessionals' (Kritzer, 1999, p. 713). Muzio and Ackroyd (2005) observe that external pressures have mainly resulted in increased internal stratification within law firms. In this context, the term

\footnotetext{
${ }^{2}$ The latter group's status is strongly connected to or derived from the 'full' professional.
} 
'deprofessionalisation' has been used. However, we believe (with Paterson, 1996) that this movement can better be recognised as creating an altered form of professionalism rather than resulting in deprofessionalisation. Professional values still occupy a central place in the execution of the profession but are under pressure by other values and are therefore transformed and relocated within the professional institutions.

While the aforementioned literature mainly discusses the position of legal practitioners, there is a fair amount of literature that observes that a worldwide movement to managerialise public-sector institutions has also affected the administration of justice at state institutions (see Freiberg, 2005; Heydebrand and Seron, 1990; Raine and Willson, 1997; Mak, 2008; Hondeghem et al., 2016; Lienhard et al., 2012; Visser et al., 2019). Managerial influences on the administration of justice are, for instance, observed in the US (Heydebrand and Seron, 1990), Australia (Freiberg, 2005; Spigelman, 2001) as well as in various European countries (e.g. for the UK, see Raine and Willson, 1997; McLaughlin et al., 2001; for France, see Vigour, 2015; Mak, 2008; for Switzerland, see Lienhard et al., 2012; for the Netherlands, see Visser et al., 2019; Langbroek and Westenberg, 2018; Mak, 2008). This movement, under the name New Public Management (NPM), stems from organisational theories and focuses on public accountability and the use of best practices from the private sector to improve the quality of services provided by public-service organisations (see e.g. Hood, 1991). Private-sector principles, such as efficiency, effectiveness, transparency and accountability, have become guiding concepts and are widely adhered to in courts and public prosecution offices. This is accompanied by the introduction of private-sector techniques, such as incorporating systems to 'measure' court performance and processes and incentives to increase the efficiency of courts (Contini and Carnevali, 2010).

While the NPM approach could be regarded as a welcome initiative to help reduce the backlog of cases and improve the quality of justice (Contini and Carnevali, 2010; Jean and Pauliat, 2006), it generates resistance from the professionals working within the system (Vigour, 2006; 2015; Holvast and Doornbos, 2015). This is partly related to the fact that the introduction of NPM principles is often accompanied by - or at least associated with - cuts in the budgets of the organisations. However, professionals hold more general objections to the movement. Judges particularly fear that NPM principles will impede traditional professional and legal values, such as judicial independence, impartiality and most importantly - autonomy (Langbroek, 2001; see in relation to legal-aid practice Sommerlad, 1995). In fact, it is a much wider grievance that managerialism hinders the autonomous position of professionals. Similar concerns are raised within the health sector and (higher) education (Bezes et al., 2012).

Professional workers are likely to oppose these managerialism influences, for example by creating sets of self-binding conditions for entering the profession and for performing the professional duties. These self-binding conditions (are proclaimed to) accommodate the provision of high-quality services. At the same time, and some authors argue that this is their core purpose, the conditions also function as a means to maintain a professional monopoly of the services offered by the profession (Larson, 1977). Professions will therefore be resilient to changes that challenge the existing system of professional self-organisation and self-control (see e.g. Freidson, 2001). They find it problematic to accept that paraprofessionals can and should perform parts of the professional duties, as it means giving up part of the professional monopoly of providing legal services. However, it has become increasingly clear that this is a lost battle, as the market mechanism forces legal professionals to give up part of this monopoly to become more affordable (Susskind, 2017). This introduces new forms of professionalism and results in paraprofessional positions becoming more professionalised, a notable example being paralegals in law firms (Noordegraaf, 2011; Lively, 2001).

\subsection{Methodology}

This paper combines a macro-level analysis of regulation and policy on the role of paraprofessionals with micro-level insights from empirical data collected through participant observations and interviews within the Dutch judiciary and the PPS. For the regulation and policy analysis, we studied the literature on organisational developments within both institutions and conducted a review of 
policy documents published by the Council for the Judiciary (Raad voor de Rechtspraak), the Board of Prosecutors General (College van Procureurs-Generaal) and the Dutch Association for the Judiciary (Nederlandse Vereniging voor Rechtspraak, the professional body and trade union for judges and public prosecutors).

The previous documents report only marginally about the role and duties of assistants and they provide little insight into the daily practice in the workplace. In order to gain more in-depth information, empirical data were needed. The empirical data derive from two research projects ${ }^{3}$ : one on the work of public prosecutors in the Dutch PPS and another project on the involvement of judicial assistants in judicial decision-making at Dutch district courts. In the first project, Lindeman studied how public prosecutors define and fulfil their duties. He conducted fieldwork for the duration of twelve months within two district offices and one nationwide office of the PPS. He followed the prosecutors in their daily routine and observed their interactions with the PPS staff, police officers, judges, etc. He was able to observe how prosecutors interact with prosecution assistants and to what extent they follow the assistants' judgments. During his fieldwork, he observed and spoke with numerous prosecution assistants. He also conducted fifteen interviews with prosecutors. ${ }^{4}$ In the second project, Holvast examined the involvement of judicial assistants in the judicial decision-making in two Dutch district courts (in the criminal-law and administrative-law divisions). She conducted fieldwork for the duration of eight months. Holvast participated in the daily activities of the courts and followed the decision-making process in 137 cases, heard during twenty-seven hearings. She analysed the exchange of views orally and via memos prior to the hearing, observed the hearings and was able to attend and observe the deliberation sessions. She also examined the process of drafting and finalising the judgment by judges and assistants. Holvast interviewed over eighty court officials, mainly judges and judicial assistants. ${ }^{5}$

\section{The Dutch context: changing position of paraprofessionals in the judiciary and the PPS}

In the 1990s and 2000s, the Dutch administration of justice has adopted various NPM features (see more in Visser et al., 2019). The introduction of these features affected the formal position of paraprofessionals in the Dutch judiciary and the PPS in different ways. In both institutions, we observed that paraprofessionals have received a more central position in the work processes. However, the changes in the position of the paraprofessionals in the PPS are more far-reaching and more explicit than in the judiciary. We start this section by providing a brief description of the organisation of both institutions. Subsequently, we successively summarise the changes that occurred regarding the position of paraprofessionals in the judiciary and the PPS.

\subsection{Managerial changes in the Dutch judicial and public prosecution organisations}

While we portray judges and prosecution officers as professionals, and thereby compare them to other professionals such as doctors, professors and attorneys, it is important to note that judges and prosecutors have a special position in society. In the Netherlands, both officials are appointed by law as a so-called 'judicial civil servant' (rechterlijk ambtenaar, Art. 1 of the Judicial Organization Act), providing them with a special legal status codified in the Act on the Legal Status of Judicial Civil Servants. This differentiates them from other civil servants and gives them, in some ways, the status of personification of the administration of justice (one of the three branches of state power) (Langbroek and Westenberg, 2018). Especially for judges, this position also comes with various safeguards regarding their independence, impartiality and integrity: judges are appointed for life (Art. 116 of the Dutch Constitution) and special rules for dismissal apply to 'judicial civil servants'

\footnotetext{
${ }^{3}$ These two PhD projects by Holvast and Lindeman were published in 2017.

${ }^{4}$ See more in Lindeman (2017, chapter 2).

${ }^{5}$ See more in Holvast (2017, chapter 2).
} 
(Bovend'Eert, 2000). These safeguards apply to public prosecutors to a somewhat lesser extent: they are not appointed for life and the Minister of Justice can give directions to the Public Prosecutor's Office (Van de Bunt and Van Gelder, 2012).

Judicial assistants are defined in the Judicial Organization Act as 'civil servants who work at courts'. Prosecution assistants are regular civil servants and are implicitly referred to as 'other civil servants working at the prosecutor's office'. ${ }^{6}$ The regular terms of appointment and dismissal for Dutch civil servants apply to both types of assistants.

The formal status of 'judicial civil servants' also resonates in the way judges and prosecutors view their position and how they act. In the Netherlands, this is often referred to as their 'magisterialness' (in Dutch magistratelijkheid, which refers to a mindset of making independent decisions as a guardian of the rule of law, thereby considering the interests of all parties involved). For prosecutors, magisterialness means that they are not merely a party in criminal proceedings seeking to 'win' a case: they are expected to oversee a process of establishing the truth that is compatible with the rule of law (Lindeman, 2017, pp. 24-26, 295). Developing and maintaining the attitude of a magistrate is part of the professional training of judges and prosecutors. This magisterial position is most absolute for judges (as adjudicators) and somewhat less for prosecutors, who have to comply with criminalpolicy regulations (Van de Bunt, 1985; Lindeman, 2017).

The special position of judges and prosecutors has always been important for the organisational structure of their respective institutions. Traditionally, the judiciary and the PPS were managed by the judges and prosecutors. At all courts, the periodical 'court meeting' (gerechtsvergadering), consisting of all judges, used to be an important decision-making body. These local bodies still have some decision-making power, but a more managerial structure was introduced in 2002, with the newly established national Council for the Judiciary at the top. At the court level, an additional management layer consisting of judge team leaders was introduced and the courts' boards were required to include one non-judge board member. Another important change was the introduction of output financing. These changes resulted in a somewhat more managerial organisation, in which collective work processes are - to some extent - restricting the autonomy of judges and moving more towards a 'controlled professionalism' as described by Noordegraaf (2015). Nonetheless, the autonomous position of judges and their authority in organising their work are still key elements within the judicial organisation. Hence, the NPM values have not replaced the traditional rule-of-law values, but these values co-exist (Mak, 2008; Langbroek and Westenberg, 2018).

The organisational structure of the PPS has changed more radically. Significant NPM influences can be recognised in these developments. As within the judiciary, these influences also restrict the autonomy of prosecutors. In order to understand the impact of the changes, a short introduction on the organisation of the PPS is necessary (Zouridis, 2016).

The PPS has authority over the police in criminal matters and decides whether to prosecute or dismiss a case (along the lines of the so-called expediency principle). In the 1970s and 1980s, the Dutch government increasingly regarded criminal policy as a means to proactively fight crime and the PPS was supposed to be the 'spider in the web' in this battle. However, in the 1990s, it became clear that the PPS was not up to this task. After long deliberations, legislation implementing rigorous changes in the management structure of the PPS came into force in 1999. A 'top-down' hierarchy was introduced, formalising the (until then informal) leadership by the Board of Prosecutors General, but still allowing the Minister of Justice to issue instructions to that board. Also, the practice to shift a part of the prosecutors' work to subordinates had a statutory basis that allowed a much broader application. Policy regulations issued by the Board of Prosecutors General became increasingly important instruments. These regulations constrain the discretionary role of individual prosecutors, as they hold instructions regarding the decision to prosecute.

Since the formal reorganisation in 1999, the PPS has almost continuously been engaged in revising and adjusting its organisation, for example by increasing the scale of the offices. ${ }^{7}$ Since the 2008 crisis,

${ }^{6}$ Judicial Organization Act, Art. 126.

${ }^{7}$ The Judicial Revision Act merged nineteen district offices into ten. 
budget cuts have been a rule rather than an exception, urging the PPS to work as efficiently as possible, without losing sight of the primary objectives. As of 1 January 2019, the PPS also introduced output financing for a significant part of the organisation. These developments within the PPS display a strong pattern of centralisation of authority and a mandatory accountability within a strict hierarchy, to a certain extent even involving accountability to the Minister of Justice.

These organisational changes in the institutions also had consequences for the position of paraprofessionals. We will discuss this position in the next sections.

\subsection{Paraprofessionals in the judiciary}

The paraprofessional, in the capacity of court assistant (griffier), has a long history in the Dutch judiciary, existing since the early 1800s (De Groot-van Leeuwen, 1991). Other than preparing the court record, which has been a key responsibility since their existence, duties of these assistants have changed drastically over time. From the 1960s to the 1980s, a substantial portion of the assistants consisted of internally trained, originally administrative, staff members. From the 1990s onwards, and particularly after the enactment of new legislation, their position was gradually professionalised. The largest change occurred after the introduction of the new management structure with the enactment of the Dutch Judiciary Organization and Management Act (Wet Organisatie en bestuur gerechten) and the Act on the Council for the Judiciary (Wet Raad voor de Rechtspraak), in 2005. The numbers of judicial assistants working at the courts vary somewhat per court type and division but, at district courts and Courts of Appeal, the judicial assistants slightly outnumber the judges working at the courts (see Holvast, 2017, p. 49). ${ }^{8}$

To implement the output-based financing structure that was introduced in 2005, the judiciary created a model that specifies how much time (measured in minutes) a judge and a judicial assistant are estimated to work on a specific type of case: the so-called Lamicie-model (see Van der Torre et al., 2007). The model determines what compensation courts subsequently receive for handling the cases, taking into account the supposed time spent on handling those cases by the judicial officers (Van der Torre et al., 2007). The figures are based on time writing surveys and are supposed to reflect the real division of work within the courts. The model revealed the practice that, in most types of cases, judicial assistants spend considerably more time working on the cases than judges. Shortly after the creation of this model, the internal training programme for judicial assistants deteriorated and the minimum requirement for holding a diploma from an institute of higher professional education was introduced (Abram et al., 2011). The latter was primarily a codification of an already existing practice. In fact, many newly hired assistants had (and still have) finished even higher levels of education (an LLM from a Dutch law school). The function of judicial assistants in district courts and civil and criminal Courts of Appeal have, since 2007, been divided into five categories: junior judicial staff members, judicial staff members, senior judicial staff members, staff lawyers and senior staff lawyers. The function profiles provide insight into the duties of judicial assistants. These profiles state that (both junior and senior) judicial assistants assist judges in preparing for hearings, during the hearings and in the processing and conceiving of judgments. Staff lawyers are usually specialists of a subfield of law. They are required to possess an LLM from a Dutch law school. Staff lawyers may provide advice on complex legal issues and cases with high social or economic impact. Additionally, they can contribute to the creation of new case-law and serve as sounding boards for judges and judicial assistants. The descriptions of duties in the profiles, however, remain abstract and can be interpreted in multiple ways. The function profiles do not indicate the manner in which judicial assistants are supposed to assist prior to the hearings or how to give advice. The profiles also do not mention the assistants' role in the deliberation room; the research by Holvast (2017) revealed the informal norm that judicial assistants do participate in judicial deliberations.

It can be extracted from the aforementioned documents that judicial assistants have attained a more central position within the process of adjudication. Several professional duties that were originally

${ }^{8}$ Unfortunately, no historic comparison can be provided; these numbers only recently became available. 
reserved for judges are now partly conducted by judicial assistants. The transformation of the judicial-assistant position that occurred over time appears to follow from NPM-driven organisational changes, such as the output-based financing structure and efforts to improve the efficiency of work processes. The required qualifications for the function have become stricter and an assistant's current role exceeds the more administrative tasks that the role primarily consisted of before. Most judges and assistants who worked at the courts during these transitions confirm that the judicial-assistant position has tacitly become more demanding. Examples thereof are the acceleration of the duties to draft judgments and the assistants' active participation in deliberation sessions. The fact that the position of judicial assistant nowadays requires more legal knowledge and skills is most recently used as leverage in the negotiations of the collective labour agreements of judicial assistants. However, as of today, many judicial assistants have temporary contracts and most assistants' salaries are based on a scale for graduates from Universities of Applied Sciences, even though the vast majority have graduated from regular universities.

\subsection{Paraprofessionals in the PPS}

\subsubsection{Formalised mandate for prosecutor assistants}

The idea to allow prosecutors to delegate additional duties to assistants developed as early as the 1970s. That is not to say that delegating these duties was immediately a widespread practice. At first, prosecutors were reluctant to allow the paraprofessionals to perform some of their duties (Van de Bunt, 1985). After all, these assistants did not possess a law degree and, as such, acquired their knowledge 'on the job'. At the same time, the case-load gave the prosecutors no choice but to allow assistants to at least prepare their cases for them. This practice was facilitated by the prosecution guidelines, supporting the assistants in their decision-making process. This deployment of assistants increased over the years, without a clear legal basis: the public prosecutor would still formally make the decisions. This changed in 1999 when the legal amendments mentioned above provided a formal mandate to assistants within the PPS to perform certain duties normally reserved for public prosecutors. ${ }^{9}$ Thus, while, in the judiciary, assistants work under the direct authority of a judge, prosecutors' assistants have been mandated to make individual decisions for the past two decades.

As such, in the 1990s and 2000s, NPM principles were more and more incorporated into the PPS organisation. On the one hand, prosecution assistants increasingly were university graduates. On the other hand, the PPS also started employing new types of assistants with lower education levels. Between 2000 and 2015, a broad range of assistants with varying levels of education were employed by the PPS: administrative judicial assistants (senior secondary vocational education) ${ }^{10}$; junior prosecution assistants (higher professional education) ${ }^{11}$; prosecution assistants (higher professional education or university education) ${ }^{12}$; and senior prosecution assistants and (senior) policy officers (mostly university education). ${ }^{13}$ Nonetheless, even the assistants with the lowest rank (administrative judicial assistants) were mandated to process and decide on (the most simple) cases.

\subsubsection{The role of paraprofessionals in FOO and HIC}

The work in Public Prosecutor's Offices can roughly be divided in two work streams: frequently occurring offences (FOO) and high impact crimes/organised crimes (HIC). There are significant differences between the positions of the assistants in both divisions.

During the period 2000-2015, prosecution assistants were used extensively to process FOO. This was facilitated by an ever-increasing, intricate structure of policy regulations (guidelines and

\footnotetext{
${ }^{9}$ Judicial Organisation Act, Art. 126.

${ }^{10}$ Administratief Juridisch Medewerkers who received middelbare beroepsopleiding (MBO).

${ }^{11}$ Junior Parketsecretaris (hoger beroepsonderwijs, HBO).

${ }^{12}$ Parketsecretarissen, $\mathrm{HBO}$ or universitair onderwijs.

${ }^{13}$ Senior Parketsecretarissen and (senior) beleidsmedewerkers, Universitair geschoold.
} 
instructions) and ICT systems, which allowed assistants to work independently while still being monitored (Van de Bunt and Van Gelder, 2012; Lindeman, 2017). ${ }^{14}$ Almost 50 per cent of the cases registered by the PPS were dealt with out of court. ${ }^{15} \mathrm{~A}$ vast majority of these cases were processed by assistants. This allowed a so-called bifurcation: prosecutors dealt with more serious and/or complicated cases, while assistants processed the run-of-the-mill cases.

Assistants decided whether cases went to trial or were handled out of court. They decided which offence a suspect would be prosecuted for and (in the case of out-of-court proceedings) on the type and measure of the sentence. Lindeman (2017) observed that there was not much scrutiny of the assistants' work. The FOO departments of the PPS district office virtually operated on a 'stand-alone' basis. Prosecutors would only be involved if a case was taken to court because a suspect did not agree to the proposed out-of-court sanction or if an assistant decided to summon the suspect.

A highly critical report on the efficiency of the criminal justice chain (Algemene Rekenkamer, 2012) led to the implementation of a new procedure regarding FOO: the so-called ZSM procedure (Jacobs and Van Kampen, 2014). ${ }^{16}$ In a significant departure from the practice described above, the aim is now that all cases are preliminary decided upon by a prosecutor in an early stage. The prosecutor gives an indication as to the processing (a trial or an out-of-court proceeding). Subsequently, a prosecution assistant will execute this decision or, if necessary, prepare the case for trial. The use of prosecution assistants without legal training has diminished.

A new function, the 'assistant-prosecutor', has been introduced. (Senior) prosecution assistants with a law degree can enter a traineeship to become an assistant-prosecutor. An assistant-prosecutor is always on duty together with a regular prosecutor at the ZSM desk. Those cases that will be routed towards a trial will, ideally, be processed by this assistant-prosecutor, who will also represent the PPS at the trial. The assistant-prosecutor will also represent the PPS at trial in other simple cases, mostly heard by a single judge. In doing so, the assistant-prosecutor takes over a significant part of the workload traditionally assigned to regular prosecutors. Initial research by the Dutch Association for the Judiciary and follow-up research by the Board of Prosecutors General reveal that there are differences between the districts as to the scope of the competence and autonomy of assistant-prosecutors. It is not always clear whether the various manifestations of the assistant-prosecutor are in line with the national policies.

While prosecution assistants have increasingly been assigned more demanding duties, their salary grade has remained almost unchanged and they rarely have permanent contracts. Even becoming an assistant-prosecutor is by no means a guarantee to enter the traineeship to become a fully qualified public prosecutor.

In the departments where more serious and/or complicated criminal cases are dealt with and where prosecutors oversee the criminal investigations carried out by the police, also known as the HIC departments, (senior) prosecution assistants play a significant role. The role of prosecution assistants within these more complicated criminal cases is more commensurate with the role of judicial assistants. The legislation on their mandate does not allow the prosecution assistants to make independent decisions on the use of investigation methods (e.g. wire taps or surveillance orders) and/or coercive measures. However, the assistants do often offer significant assistance to the prosecutors.

\subsection{Concluding remarks}

In the past decades, the (formal) division of duties between professionals and paraprofessionals has been altered. More specifically: further allocation of duties to paraprofessionals has occurred. Within both institutions, these changes can, at least in part, be attributed to the NPM movement. At the PPS, some of the decision-making practices have increasingly been mandated to assistants,

\footnotetext{
${ }^{14}$ This ICT system called the Decision Support System, Beslissingsondersteuningssysteem - BOS, was used from the start of the reorganisation in 1999 until 2015

${ }^{15}$ This figure has been quite consistent over the past decades.

${ }^{16} \mathrm{ZSM}$ stands for 'zo snel mogelijk' which translates as 'as soon as possible'.
} 
which transferred them into some sort of quasi-prosecutors, culminating in the establishment of assistant-prosecutors. In the judiciary, all decision-making duties are still formally in the hands of the judges, with no official mandates for decision-making by judicial assistants.

In both institutions, the official recognition of more demanding paraprofessional functions is still limited: neither the financial compensation nor other forms of appreciation have shown meaningful improvement. Additionally, the official policy provides general guidelines, but leaves a significant margin of discretion as to how the professionals and paraprofessionals should give substance to their collaboration, leaving room for differences in execution. This makes it interesting to investigate which - largely informally defined - standards/norms regarding the division of labour are existent at the courts and PPS, and how these are linked to different concepts of professionalism.

\section{Competing professional paradigms in the workplace}

\subsection{Introduction}

While further substantiating the professional and paraprofessional collaboration in the workplace, the (para)professionals are guided by shared professional norms and ideals regarding the appropriate position of paraprofessionals within the process of decision-making. Our fieldwork in the judiciary and PPS reveals that, among professionals and paraprofessionals, there is not one dominant paradigm that clarifies their behaviour. Two different - and on various aspects competing - paradigms co-exist and define the role of paraprofessionals.

These professional paradigms are related to the developments in professionalism described in Section 2.1. On the one hand, and that is the first paradigm, (para)professionals conform to a traditional (occupational or 'pure') definition of professionalism, in which the 'full' professional is regarded as holding the single authority over the professional decision-making. In this paradigm, it is regarded as inappropriate for the 'full' professionals to rely too strongly on the work of paraprofessionals. The professionals claim full jurisdiction over the process of adjudication/prosecution and the position of paraprofessionals is - in some occasions - marginalised. On the other hand, a second paradigm exists, which encompasses that professionals and paraprofessionals accept that their relationships have changed and that managerial indicators regarding productivity and policy influence their work, and they acknowledge that paraprofessionals can - to some extent - be regarded as professionals themselves. Within this paradigm, all officers at the court/PPS are viewed as partners in reaching the goal of delivering justice in an efficient and timely manner.

Some (para)professionals have ideas that predominantly fit into one specific paradigm. More often, professionals' and paraprofessionals' behaviour appears to fit in both paradigms, opting for different sets of norms in different situations. In the following sections, we provide a detailed account of how we recognised these paradigms in the statements made and actions taken by professionals and paraprofessionals.

\subsection{The 'pure professional' paradigm: emphasising the superior status and authority of the judge/ prosecutor}

On various occasions, we observed a scepticism towards a movement that would assign more farreaching adjudicative or prosecutive duties to paraprofessionals. Several times an inherent hierarchy in the relationship between professionals and paraprofessionals was emphasised by respondents. They related this to the fact that the judge/prosecutor is the one appointed by law to adjudicate/prosecute. This claim of authority is more obvious with regard to judges (see Section 3.1) and this was indeed a stronger sentiment within the judiciary. However, prosecutors also expressed this claim of authority. The 'full' professionals thereby displayed behaviour of marking the boundaries of their profession and being resilient to changes in work processes that might challenge these boundaries - which can be regarded as typical behaviour for 'pure professionals'. It is interesting that not just professionals, but also several paraprofessionals defend these strict boundaries. 
Some authors suggest that the sense of responsibility for judgments (and in this context also decisions to use coercive measures, prosecute and/or demand a sentence) might be lost when paraprofessionals are involved (Fiss, 1983; Hol, 2001). Despite our finding that, indeed, paraprofessionals are involved to a greater extent in the decision-making process, a decline in a sense of responsibility was not generally observed in our research. ${ }^{17}$ One judge, for example, stated:

'I make the decision. It is my responsibility, and I have to carry it. And if we can't decide, I am the one who lies awake at night, not the judicial assistant. He will hear the next day what we're going to do.' (A1 - resp. 18)

Judges' responsibilities appear to rest heavily on their shoulders. Relying too strongly on the products of judicial assistants is, from this perspective, excluded. Judges draw a clear line at the use of memos produced by judicial assistants. All judges proclaimed that it is inappropriate to prepare for a hearing by exclusively reading the memo prepared by an assistant and not opening the case files. One judge's (A1 - resp. 38) opinion was more extreme. He said he did not read the memo at all, as he wanted to enter the hearing unbiased. However, this was not the leading opinion within the courts.

In the HIC division of the PPS, a similar claim of authority was displayed. Prosecutors claimed that assistants hardly ever made decisions without prior consent by the prosecutor, especially when it concerned decisions on the application of the expediency principle:

'It's an equal debate, but at the end of the day, the decision has your name on it, and you will be the one having to discuss the decision with parties concerned. No, I don't think that decisions leave this office without the involvement of a prosecutor.' (A2 - resp. 10)

While the social boundaries between the groups of professionals and paraprofessionals have faded in the past decades and the interaction has become more informal (on the PPS in the 1980s, see Van de Bunt, 1985; on the judiciary, see Bevers, 2004, pp. 8-9), these boundaries have not disappeared completely. A judge (A1 - resp. 42) explains that, when she started working in the judiciary around the turn of the century, it was explained to her that judges were not supposed to socialise too much with assistants, as that was unworthy of their rank. Within some court divisions, it was still common in 2012-2013 for judges and assistants to have lunch in separate groups. This demonstrates that - to some extent - a social distance still exists. Judicial assistants would, on average, also speak considerably less than judges during general staff meetings that were held in different courts. According to some respondents, this can be explained by the often more timid nature of assistants, related to the fact that they chose to fulfil a subordinate role with no decision-making responsibilities. Observations within the PPS were somewhat different in this regard: especially within the HIC teams, some assistants played dominant roles in team meetings. Also, socialising between prosecutors and assistants was customary, which, in the 1980s, would have been unthinkable (Van de Bunt, 1985). Despite prosecutor and assistant positions growing towards each other, periodical 'prosecutors-only' meetings were still being held (Lindeman, 2017).

The previous paragraphs clearly indicate that both judges and prosecutors believe that there is a certain domain of authority exclusive to their profession. In the judiciary as well as in the PPS, we observed significant differences between individual judges/prosecutors as to the exact dimensions of that domain.

The appearance at the public hearing was generally regarded as one of the key components of the profession of judge or prosecutor, which clearly distinguished these professionals from the paraprofessionals. Several assistants mentioned that they actually prefer a position out of the spotlight and believed themselves to be more suitable for such a role. At the courts, a marginal change occurred

\footnotetext{
${ }^{17}$ But see Section 4.3.1.
} 
in which, in administrative-law cases, some judges would allow assistants to ask questions to the parties (which in reality rarely happened). At the PPS, a notable shift in this regard is the introduction of the assistant-prosecutor (see Section 3.3).

Still, a large portion of the judges and prosecutors believed that performing at the hearing was typical for their profession. This also demarcates their professional position to the general public. These professionals reject the possibility of having assistants involved. When the researcher, for instance, asked a judge about her view on having judicial assistants ask questions, she responded: 'No, that cannot happen, because the assistant is not present to ask questions during the hearing. If that happens during a hearing where parties are present, then it is wrong. Period' (A1 - resp. 50).

In summary, we observed (para)professionals who (still) adhere to traditional professional values, as described in the original literature on professionalism when it concerns certain parts of their work (see Larson, 1977; Abbott, 1988; Freidson, 1994).

\subsection{The 'new' professionals paradigm: judges/prosecution officers and assistants as partners in reaching professional goals}

\subsection{1 (Para)professionals taking into account 'new professional' values in their professional collaborations}

While we observed claims made regarding the hierarchy in the relationship between professionals and paraprofessionals, the equality in and similarities of the positions were just as frequently mentioned. Many judges underlined that they acknowledged judicial assistants for being colleagues with whom they closely collaborate in the process of adjudication and interchange intellectual ideas regarding the merits of cases. Assistants are often also regarded as equal partners by the HIC prosecutors and are welcomed to discuss almost all decisions with the prosecutor. Lindeman (2017) heard a prosecutor make the off-the-cuff claim that assistants could perform all the prosecutor's tasks, except for the trial (A2, p. 105). A judge similarly said: 'A judge is actually a sort of assistant plus: he should be able to do everything that an assistant can and chair the hearing' (A1 - resp. 77).

Judges and prosecutors regularly work with the same assistants, which can attribute to a certain team spirit. The fact that the majority of recently appointed judicial/prosecution assistants obtained a law degree appears to be important for judges and prosecutors to acknowledge them as discussion partners: 'I always think: we employ lawyers for a reason .... We should make use of that' (A1 resp. 42). Various respondents also highlight the sounding-board function of the assistants and they recognise that the discussion with the assistants affects their considerations regarding cases. One judge explains how she, somewhat to her own surprise, really missed this type of contribution when - due to unforeseen circumstances - she was not accompanied by a knowledgeable assistant:

'I realized that I really missed a discussion partner then.... I really missed someone to write the judgments. That, too. ... But I mainly noticed that what I really missed was the exchange of thoughts. I didn't expect that to be such an issue.' (A1 - resp. 42)

The discussion-partner role of judicial assistants is also exposed by the informal norm (largely given substance since the 1990s) that judicial assistants are asked to display their views on the case during deliberation sessions. ${ }^{18}$ Some judges regard this as a duty, emphasising their equal position in the discussion of cases. Others consider this more to be a privilege or a social gesture, which they imagine assistants will appreciate. In the administrative-law sections of the courts, it is common practice in single-judge cases for the judge and judicial assistant to meet after the hearing to discuss the cases. It is remarkable that these meetings are referred to as 'deliberation sessions', while formally the

\footnotetext{
${ }^{18}$ Although, in the interviews, judges widely endorse this informal work practice, they do not always act accordingly during the deliberation sessions (perhaps due to 'pure' professional ideas). In just over half of the deliberations observed by Holvast, the assistants were consistently offered the opportunity to speak first.
} 
judge takes the decision and, thus, actual deliberation is not a necessity. Most of these sessions appeared to occur on equal grounds, with both participants being actively involved in exchanging different arguments regarding a case. A similar practice can be found in the various forms of peer sessions that prosecutors convene on a regular basis. For example, 'sentence assessments' ${ }^{19}$ regularly take place. A prosecutor presents his/her case to other prosecutors with the objective of assessing the demand (regarding the sentence) that fits the crime best. The assistant who worked on the case with the prosecutor is also invited and actively participates in the meeting.

Furthermore, judicial and prosecution assistants have another important means of sharing their views on the case: the preparatory memos that they make for judges and prosecution officers to prepare for the hearings (see on the importance of these memos in Dutch police judge cases also Van Oorschot, 2014). Some of these memos are mainly summaries of the case files, yet other memos clearly, and deliberately, reveal the views of the assistants on the demands that the prosecutor should present or what the judges' decision should be. In some administrative-law cases, judicial assistants would write memos in a draft-judgment format, thereby to an extent already anticipating the legal reasoning. In complicated cases, the prosecution assistant who assisted in conducting and overseeing the investigation and who prepared the case will attend the hearing before the trial such as to be able to assist the prosecutor when last-minute questions arise. Hence, while judges and prosecutors are by law required to act and decide in specific situations, the preparations of an assistant are by many considered indispensable for these actions and decisions. This indicates that these professionals acknowledge that their work is to some extent 'controlled' by decisions about work processes - and the role of paraprofessionals therein - made on an organisational level (see Noordegraaf, 2015).

At the HIC departments, when the police need a warrant for a specific investigative method, ${ }^{20}$ assistants will draw up the warrant (and determine whether there are sufficient grounds that meet the legal requirements). Assistants draft orders for pre-trial detention. Assistants prepare meetings with the police in ongoing investigations, and they even represent the prosecutor in such meetings. Some prosecutors (but certainly not all) sometimes temporarily yield some of their authority and allow assistants to decide on the arrest of persons 'not caught in the act', even when there is no legitimation for such a mandate. The prosecutor will insist on being briefed on such decisions straightaway (Lindeman, 2017).

Prosecution assistants also play important roles in the policy-related duties of public prosecutors. They prepare and attend selection consultations with the police, in which the case-load of HIC cases will be prioritised. They also prepare and attend tri-party consultations in which the city mayor, the chief of police and the public prosecutor discuss priorities regarding enforcement of crime and public order within districts.

Hence, in this second paradigm, we observe (para)professionals taking into account 'new professional' values in their professional collaborations. Thus, we observe that (para)professionals are aware of various values of which the importance was stressed in the NPM movement. ${ }^{21}$

\subsubsection{New professionalism in the extreme: the PPS 2000-2015 22}

In the FOO divisions of the PSS, we observed an example of an extreme form of the 'new professionals' paradigm in which professionals do not so much work together to reach professional goals, but rather work on reaching these goals separately.

\footnotetext{
${ }^{19}$ Strafmaatoverleggen.

${ }^{20}$ Dutch law requires these warrants for many investigation methods, such as surveillance orders, requisition of information (e.g. CCTV footage) and wire taps.

${ }^{21}$ However, because both our research projects provide an analysis of the institutions at one specific point in time, we do not claim to have proof for a causal relation and/or a gradual development in this regard. It is even likely that both sets of values have always to some extent played a part in defining work relations.

${ }^{22}$ Lindeman's (2017) observations on the FOO divisions are representative of the organisation of the processing of FOO in the timeframe prior to the ZSM procedure (roughly from 2000 until 2015).
} 
During Lindeman's fieldwork, assistants in the FOO division would work mostly independently from prosecutors and were formally mandated to independently decide cases. Prosecutors had no individual say as to which assistant processed which cases: management and policy regulations had taken over that part of the process and prosecutors often only came into play once a case ended up before the court. Prosecutors did not have the time or the means to actively interfere in those cases at an earlier stage. The decisions were made at great distance from the prosecutor. Therefore, the prosecutors did not claim authority over the cases: 'Misdemeanors; I do have them [cases prepared by prosecution assistants] at my hearings, but they do not feel like my cases' (A2 - resp. 7).

At the same time, the prosecutors were not content with this division of duties because they regularly noticed mistakes and/or omissions in cases that would end up in court hearings that they had to prepare. Prosecutors commented on the undesirability of this situation, while at the same time emphasising that it was out of their hands. As a consequence of omissions in the files, they sometimes would ask for an acquittal or a stay of proceedings. One prosecutor (A2 resp. 7) admitted to being aware that, due to a lack of scrutiny by the responsible assistants, people were paying fines for behaviour that was not necessarily liable for punishment. Still he admitted that he did not make the effort to raise awareness on this topic with the responsible assistants, nor with other prosecutors, nor the leadership of their district office. Another prosecutor (A2 - resp. 1) referred to similar issues as a 'business risk', while at the same time admitting that he believed it to be frustrating and that it could affect the credibility of the PPS. Thus, the prosecutors did feel that they should have authority over the process, but perceived that - in reality - it was out of their control. They considered this to be primarily a problem for the institution rather than for them as professionals. It is in this regard that we observe how the organisational control strongly affects the division of duties between professionals and paraprofessionals, which leads to a decline in the sense of responsibility (discussed earlier in Section 4.2 above) that we did not observe as strongly in other divisions.

In most situations described under this paradigm of 'new professionals', we see professionals acting as 'hybrid professionals' who combine pursuing professional standards with managerial requirements (see Noordegraaf, 2007). However, the situation at the FOO divisions appears to be one in which the professionals try to meet professional standards but the managerial set-up hinders them from meeting both requirements. This situation has somewhat changed since the introduction of the ZSM procedure (discussed in Section 3.3). One of the aims of this alteration was to increase the commitment of prosecutors to FOO cases. In practice, however, a lot of cases are still processed by assistants, who have now been promoted to 'assistant-prosecutors'.

In the following section, we discuss some consequences of two co-existing, and in some respects conflicting, paradigms regarding the role of paraprofessionals.

\section{Analysis of practices in the workplace}

This section analyses the daily practices that we observed. We demonstrate how the two paradigms that shape the thinking about professional-paraprofessional relations played out at the level of the workplace. When analysing the judiciary and the PPS, first of all, we observe one major collective finding, which is related to the (para)professionals' juggle between the different paradigms (see similarly Schott et al., 2016). Namely, we observed great variation on a workplace level in the manner in which professionals and paraprofessionals divide tasks and give substance to their collaboration. We thereby observe that the type of collaboration and the level of delegation of authority differ greatly, depending on the type of cases, being either routine cases or complex cases. This - sometimes inexplicable - variation also results in an ambiguity in the relationship between professionals and paraprofessionals. Second, we find that organisational aspects do - sometimes greatly - influence the nature and degree of collaboration and delegation. This influence is particularly visible in the PPS and is more subtly observed in the judiciary. 


\subsection{Great variation and ambiguity in the professional-paraprofessional collaboration}

On the one end of the spectrum, we observe occasions on which the professional hardly utilises the paraprofessional, other than for purely administrative and secretarial tasks. This occurs mainly in the judiciary. Some judges tend to check all the products of judicial assistants extensively, especially when they consider a judicial assistant to be less meticulous. Other judges simply make little use of the memos and drafts produced by assistants.

On the other end of the spectrum, we observe occasions on which the professional utilises the paraprofessional to the extent that they leave a large part of the initial decision-making up to the paraprofessional and the professional mainly functions as a controller at the end of the process. The most extreme example of this form of collaborating has been described above regarding the FOO division of the PPS, where prosecutors have given up part of their professional territory.

This substantial variation is partly related to the variety in needs with regard to assistance in different types of cases; each case requires different legal research to be conducted as well as different clerical assistance.

\subsubsection{Different levels of delegation of authority in complex and routine cases}

To anyone with an understanding of the diversity of cases that are handled by the PPS and the judiciary, it will not be surprising that different types of cases demand a different paraprofessional contribution. Among other aspects, this depends on the type of legislation involved, the procedure for handling the case and the content of the case. In our studies, we found a difference especially between routine, or run-of-the-mill, cases and complex cases. ${ }^{23}$

In complex cases - dealing with complex legal issues that require a modified process for handling the case, adjusted to the specifics of the case - the collaboration of professionals and paraprofessionals is quite diverse and to a large extent dependent on the specific needs of the professionals. Professionals still have significant control over the work processes and the collaboration is hardly directly affected by NPM requirements such as productivity and efficiency. Different professionals think and act differently regarding which, and how many, content-related tasks are allocated to paraprofessionals (see also Section 4). How much authority judges and prosecutors are prepared to relinquish also depends on the legal knowledge and quality they attribute to the assistants and the trust they have in them. The idea that substantial expertise and specialisation are more important for the quality of one's work than one's formal position (being professional or paraprofessional) is consistent with research conducted on the quality of legal practitioners and paralegals (see Moorhead et al., 2003).

There are few organisational guidelines regarding the collaboration between professionals and paraprofessionals in complex cases. In several of such cases, we observed collaboration on an equal basis, with paraprofessionals actively participating in the discussion regarding the merits of a case. However, in other cases, we observed professionals strongly taking the lead and allowing only a small role to be played by paraprofessionals. This was particularly observed at the courts where complex cases are regularly handled by panels of three judges. In that setting, an additional contribution to the judicial discussion by a judicial assistant was, at times, not needed. ${ }^{24}$

In routine cases - dealing with simple legal issues that can be handled in a rather uniform manner - the procedure for handling the cases is more established and regulated by organisational standards. Usually, these cases - which are the bulk of the cases at district courts and the PPS - do not require a lot of deliberations, as the outcome is clear-cut. A relatively large proportion of the paraprofessionals' duties in these cases therefore consists of administrative duties. However, in this regard, we observe different official views from the institutions regarding the extent to which judicial or prosecutorial duties can be mandated to paraprofessionals. As described above, in the FOO division, paraprofessionals are mandated to make prosecution decisions and, more recently, to even function as a

\footnotetext{
${ }^{23}$ This is a simplified dichotomy of reality, as different grades of complexity exist.

${ }^{24}$ This situation has not been observed much at the prosecution's offices, as it is not very common that multiple prosecutors deal with one case. See also Lindeman (2017).
} 
prosecutor in court. While prosecutors are at times sceptical about this delegation of authority, they accept this as something that is out of their control. In the judiciary, where the sentiment that the judge ought to have the final say is much stronger, no such official delegation of authority is observed. Even in routine cases, the judge always is the one who officially decides the cases, even though these cases are at times completely prearranged by judicial assistants. This final responsibility is considered key to many judges. One judge notes: 'He [the suspect] has the right, which is also captured in the constitution, to get the judge offered to him by law. ... So he has a right to see me. Not a judicial assistant, but me!' (A1 - resp. 38).

In short, we observe a rather varied, and in that sense also comparable, situation in courts and the prosecution office regarding complex cases. Regarding routine cases, we observe that - especially the official - delegation of duties goes much further within the prosecution office.

\subsubsection{Ambiguity on the relations between professionals and paraprofessionals}

Nonetheless, even in cases with very comparable characteristics, the type and amount of involvement of paraprofessionals vary greatly. We believe that this variance is related to the autonomy that the professionals still are given by their institutions in deciding how to collaborate with paraprofessionals. ${ }^{25}$ How the professionals give substance to their discretion appears to be dependent on the paradigms they adhere to. The unpredictability of the division of duties also results in a fair amount of ambiguity in the relationship between these officials. In the judiciary, where there is relatively little official policy that defines the role of paraprofessionals, it is unclear which informal norms should be leading when giving substance to the role of paraprofessionals in practice. In the PPS, we observed that prosecutors often were not aware of the specific requirements regarding education and/or experience for assistants: 'This is not something that was handed out to me when I started working here. I know about it in general, but if you ask me in detail, I won't know. It's not an issue that we normally encounter' (A2 - resp. 8).

Furthermore, prosecutors were not always aware of the formal limits to the mandate that most assistants were working under. Although most (para)professionals have certain, sometimes strong, ideas about the appropriate type and amount of division of labour between professionals and paraprofessionals, they are uncertain about whether and how to propagate these ideas.

As a result, judges and prosecutors only rarely talk to paraprofessionals to share their expectations about their work or provide them with feedback. ${ }^{26}$ Judicial assistants are, for instance, unsure about what is expected of them during deliberation sessions. They are regularly invited to share their views on cases at the start of the discussions in the deliberations room, but are they also expected to get involved in the discussion that follows from this? When judicial assistants have written draft judgments, judges often make adjustments to the drafts and the assistants are asked to revise them. However, the reasons for making the adjustments are hardly ever explained to the assistants. When judges were asked why they rarely shared their views on the quality and usefulness of the work of judicial assistants, they explained that this was partly because they were uncertain about the work standards that judicial assistants had to meet. Judges were especially unsure about whether they could expect that judicial assistants should function as a discussion partner.

Public prosecutors on the one hand appear more at ease about working with assistants. At the same time, they may feel that some assistants have been forced upon them: it is the organisation that decides the scope of the assistants' mandate. However, even when prosecutors are largely supportive of employing assistants, they do ask themselves what a suitable division of labour would be and what conditions would be necessary to achieve this ideal situation.

\footnotetext{
${ }^{25}$ Paraprofessionals' views also play a role in this, but a proactive paraprofessional has to first be accommodated to act as such by the professional; see also Holvast (2017, pp. 161-162).

${ }^{26}$ The absence of a culture of sharing feedback in the judiciary was also repeatedly observed by a committee that conducted inspections of the courts. See Commissie visitatie gerechten, Rapport visitatie gerechten (2014), pp. 51-55; Rapport Visitatie Gerechten (2018), p. 20.
} 
In both institutions, this results in a situation in which the conditions for fruitful professionalparaprofessional interaction remain largely unexpressed. Various paraprofessionals mention the uncertainty of this status quo. They are unsure whether they are expected to play an active role in the decision-making process, by challenging the arguments produced by the professionals, or whether they are expected to follow the instructions of professionals without asking critical questions.

\subsection{Organisation and official policy determine the work processes}

We have already given various examples of situations in which the official policy of the institutions influences the organisation of the work in the workplace. In Lindeman's study, it became clear that policy (and regulation) played an extensive role in the developments that resulted in the establishment of particular working processes. In fact, the role of policy and regulation was so extensive that prosecutors felt that they no longer had individual autonomy over the processing of cases. They were not familiar with the assistants who were mandated to decide on the cases and there was no procedure in place to provide them with feedback. This led to a disconnection between the prosecutors and the paraprofessionals. Prosecutors no longer felt that the cases dealt with in the FOO division were 'their' cases, even when they ended up having to handle the case on trial. It seems that values traditionally associated with the professional (individual prosecutors) have been appropriated by the institution and in turn have been attributed (within a strict framework of policy and regulations) to paraprofessionals. Thus, in this concrete situation, deprofessionalisation of the 'full' professional seems to take place. This is accompanied by an increasing professionalisation of the paraprofessional. The PPS has partly reversed these developments with the introduction of the ZSM procedure. However, the introduction of assistant-prosecutors reveals that prosecutors have undeniably lost territory. The introduction of this new function has met some criticism. It has been touted (by a judge) as being merely a trick with a change of labels, leading to an inflation of the position of prosecutors (Kristen et al., 2017). At the same time, prosecutors, who felt disconnected with these cases anyway, do not always mourn this 'lost territory'.

The previous developments have not been observed at the HIC divisions of the PPS and at the judiciary. The professional values and managerial requirements are in those (parts of the) institutions mainly communicating vessels. Still, it cannot be denied that organisational aspects and official policy have also been determinative for the manner in which the professional and paraprofessionals conduct their work. Due to the high workload that is assigned to prosecutors and judges (see Visser et al., 2019, pp. 45-47) and due to centrally introduced work processes introduced to increase efficiency, judges and prosecutors are not able to perform all their professional duties themselves and must rely heavily on assistants. This also results in situations in which the professionals are more or less forced to surrender part of their professional territory. Part of the work that defines the magisterial character of judges and prosecutors (e.g. forming an unbiased opinion without the risk of any prejudice when deciding on a case) has been appropriated by their institutions and attributed to paraprofessionals. While there is room left for discussion about the optimal division of duties, the effects of managerial measurements have made it difficult for judges and prosecutors to arrange significant changes in order to reclaim territory in situations that they believe need this.

\section{Conclusion}

In this paper, we described how, in the past decades, the traditionally professional-oriented organisation of the Dutch judiciary and the PPS changed, under influences such as the NPM movement. In our analysis of official documents, we find that these changes also altered the position of the judges, prosecutors and their assistants. Similarly to many other public-sector institutions as well as to legal practice, the employment of assistants has increased significantly in the judiciary and the PPS. There also has been a considerable amount of professionalisation among these assistants, to the point at which they can be referred to as paraprofessionals. Our empirical research reveals that these paraprofessionals 
play a significant role in the day-to-day work at the judiciary and PPS. Especially at the PPS, paraprofessionals have been given relatively large autonomy, by way of a mandate construction. However, individual judges, prosecutors and paraprofessionals have different attitudes towards the appropriate division of duties. In these attitudes, we recognise attributes from the traditionally leading 'pure professionalism' (which emphasises the superior status and autonomy of the professional) as well as the 'new professionalism' (which emphasises the collaborative aspect of the professional and paraprofessional in reaching professional goals). We have defined these as two competing paradigms. In practice, we observe that these paradigms are visible in different forms and variations in both institutions. The views and practices of professionals in the judiciary fit more dominantly within the first paradigm and the views and practices within the PPS (particularly the divisions dealing with FOO) fit more dominantly within the second paradigm.

It has become clear that, while professionals have continued to occupy an important position within their institutions, the managerialism of the organisational structures of both institutions has had a considerable impact on the division of duties between professionals and paraprofessionals. The new professional perspective, however, has not replaced the traditional perspective on the allocation of duties, but has set a new, more hybrid perspective in action. The co-existence of these two paradigms and the fact that both institutions have little regulation that concretely defines the territory of the (para)professionals result in a wide variation in collaboration between professionals and paraprofessionals in practice as well as in ambiguity regarding the position of paraprofessionals. Such a diversified landscape in daily practices in the workplace is not unique for our research setting. It can be distinguished in other professional settings as well (see e.g. Maynard-Moody and Musheno, 2003). In fact, many (legal) professionals are likely to struggle to define their relationship to paraprofessionals. Nonetheless, empirical evidence of such a struggle within the public justice system has been scarce up until now.

We believe that some discretion in defining the territory of professionals and the collaboration between professionals and paraprofessionals is essential, as different situations may require different professional and paraprofessional attention. At the same time, not discussing the ideals behind different practices can result in incomprehensible or arbitrary differences in the allocation of duties in the workplace. It can even result in a vacuum in which no one feels responsible anymore. A possible answer to the, sometimes inexplicable, variation in work practices and the uncertainty about the appropriate division of labour among (para)professionals might be the creation of professional standards for the employment of paraprofessionals. In order to have an actual effect on the daily work practices, we believe that it is key that not just managers, but also professionals and paraprofessionals, are involved in the creation of these standards. Additionally, if significant duties in the adjudication process are delegated to paraprofessionals, this should also be reflected in the safeguards relating to their function and in the financial compensation.

In recent publications, Noordegraaf (2015) argued that the perspective of professionalism 'beyond hybridity' may counter these issues. Professionals will have to take up responsibilities regarding the organisation of their work, so that they are not only treating cases based on parameters set out by managers (Noordegraaf, 2015; Noordegraaf and Siderius, 2016). 'Organising professionalism' means that professional workers also share a responsibility for organising the structures around their work, such as acquiring and maintaining expertise, co-operating with others (e.g. in teams), prioritising and selecting the work (bearing in mind strategic and budgetary considerations), detecting and preventing risks and failures, and accounting for their actions. We believe that this might work not only for the relationship of professionals and managers, but also for professionals and paraprofessionals.

\section{Conflicts of Interest. None}

Acknowledgements. The authors would like to thank the participants of the section seminar of the Department STeM at the Erasmus School of Law as well as Peter Mascini and the anonymous reviewers for their valuable comments on earlier drafts of this paper. 


\section{References}

Abbott A (1988) The System of Professions: An Essay on the Division of Expert Labor. Chicago: University of Chicago Press. Abel RL (2003) English Lawyers between Market and State: The Politics of Professionalism. Oxford: Oxford University Press. Abram T et al. (2011) Partners in Crime: de juridisch medewerker in de strafrechtspraak, een professional naast de rechter. Den Haag: Programma Strafsector.

Algemene Rekenkamer (2012) Prestaties in de strafrechtketen. Den Haag: Sdu.

Bach S, Kessler I and Heron P (2008) Role redesign in a modernised NHS: the case of health care assistants. Human Resource Management Journal 18, 171-187.

Bevers PJJM (2004) Samenwerken binnen de rechterlijke organisatie. Den Haag: Boom Juridische Uitgevers.

Bezes $\mathbf{P}$ et al. (2012) New public management and professionals in the public sector: what new patterns beyond opposition? Sociologie du travail 54, 1-52.

Bovend'Eert PPT (2000) Benoeming en ontslag van rechters. Deventer: W.E.J. Tjeenk Willink.

Contini F and Carnevali D (2010) The quality of justice in Europe: conflicts, dialogue and politics. Research Institute on Judicial Systems Italian National Research Council. Available at https://www.sisp.it/files/papers/2010/francesco-continidavide-carnevali-888.pdf (accessed 30 September 2020).

De Groot-van Leeuwen LE (1991) De rechterlijke macht in Nederland: Samenstelling en denkbeelden van de zittende en staande magistratuur. Arnhem: Gouda Quint.

Evetts J (2011) A new professionalism? Challenges and opportunities. Current Sociology 59, 406-422.

Fiss OM (1983) The bureaucratization of the judiciary. The Yale Law Journal 92, 1442-1467.

Freiberg A (2005) Managerialism in Australian criminal justice: RIP for KPIs? Monash University Law Review 31, 12-36.

Freidson E (1970) Profession of Medicine: A Study of the Sociology of Applied Knowledge. New York: Harper \& Row.

Freidson E (1994) Professionalism Reborn: Theory, Prophecy, and Policy. Chicago: University of Chicago Press.

Freidson E (2001) Professionalism, the Third Logic: On the Practice of Knowledge. Chicago: University of Chicago Press.

Heydebrand W and Seron C (1990) Rationalizing Justice: The Political Economy of Federal District Courts. Albany: State University of New York Press.

Hol AM (2001) De rechterlijke macht in spagaat: Over rechterlijke samenwerking en bestuurljke grenzen. In Cleiren CPM and Schoep GK (eds), Rechterlijke samenwerking. Deventer: Gouda Quint, pp. 91-100.

Holvast NL (2017) In the Shadow of the Judge: The Involvement of Judicial Assistants in Dutch District Courts. The Hague: Eleven International Publishing.

Holvast NL and Doornbos N (2015) Exit, voice, and loyalty within the judiciary: judges' responses to new managerialism in the Netherlands'. Utrecht Law Review 11, 49-63.

Hondeghem A, Rousseaux X and Schoenaers F (eds) (2016) Modernisation of the Criminal Justice Chain and the Judicial System: New Insights on Trust, Cooperation and Human Capital. Switzerland: Springer International Publishing.

Hood C (1991) A public management for all seasons? Public Administration 69, 3-19.

Jacobs P and Van Kampen P (2014) Dutch 'ZSM settlements' in the face of procedural justice: the sooner the better? Utrecht Law Review 10, 73-85.

Jean J-P and Pauliat $\mathbf{H}$ (2006) An evaluation of the quality of justice in Europe and its developments in France. Utrecht Law Review 2, 44-60.

Kirkpatrick I, Dent M and Kragh Jespersen P (2011) The contested terrain of hospital management: Professional projects and healthcare reforms in Denmark. Current Sociology 59, 489-506.

Kristen FGH et al. (2017) Evaluatie van de Wet herziening gerechtelijke kaart - Samenwerking in de strafrechtketen. Den Haag: WODC/Universiteit Utrecht.

Kritzer HM (1999) The professions are dead, long live the professions: legal practice in a postprofessional world. Law \& Society Review 33, 713-759.

Langbroek PM (2001) Quality Management and Autonomy for Court Organisations, EGPA paper 2001, Study Group on Management and Delivery of Justice, p. 6.

Langbroek PM and Westenberg MRM (2018) Court Administration and Quality Work in Judiciaries in Four European Countries: Empirical Exploration and Constitutional Implications. Bern: Stämpfli Verlag.

Larson MS (1977) The Rise of Professionalism: A Sociological Analysis. Berkeley, CA: University of California Press.

Lienhard A, Kettiger D and Winkler D (2012) Status of court management in Switzerland. International Journal for Court Administration 4, 41-67.

Lindeman JMW (2017) Officieren van justitie in de 21e eeuw: Een verslag van participerend observatieonderzoek naar de taakopvatting en taakinvulling van officieren van justitie. Den Haag: Boom Juridische Uitgevers.

Lively KJ (2001) Occupational claims to professionalism: the case of paralegals. Symbolic Interaction 24, 343-366.

Mak E (2008) De rechtspraak in balans: Een onderzoek naar de rol van klassiek-rechtsstatelijke beginselen en 'new public management'-beginselen in het kader van de rechterlijke organisatie in Nederland, Frankrijk en Duitsland. Oisterwijk: Wolf Legal Publishers.

Maynard-Moody S and Musheno M (2003) Cops, Teachers, Counselors: Stories from the Front Lines of Public Service. Ann Arbor: University of Michigan Press. 
McLaughlin E, Muncie J and Hughes G (2001) The permanent revolution: New Labour, new public management and the modernization of criminal justice. Criminal Justice 1, 301-318.

Moorhead R (2014) Professionalism: some empirical and behavioural perspectives on lawyers. Current Legal Problems 67, 447-481.

Moorhead R, Paterson A and Sherr A (2003) Contesting professionalism: legal aid and nonlawyers in England and Wales. Law \& Society Review 37, 756-808.

Muzio D and Ackroyd S (2005) On the consequences of defensive professionalism: recent changes in the legal labour process. Journal of Law and Society 32, 615-642.

Noordegraaf M (2007) From 'pure' to 'hybrid' professionalism. present-day professionalism in ambiguous public domains. Administration \& Society 48, 761-785.

Noordegraaf M (2011) Risky business: how professionals and professional fields (must) deal with organizational issues. Organization Studies 32, 1349-1371.

Noordegraaf $\mathbf{M}$ (2015) Hybrid professionalism and beyond: (new) forms of public professionalism in changing organizational and societal contexts. Journal of Profession and Organization 2, 187-206.

Noordegraaf M and Siderius K (2016) Perspectieven op publieke professionaliteit: van professionals (in organisaties) naar organiserende professionaliteit. Tijdschrift voor Management \& Organisatie 70, 4-19.

Paterson A (1996) Professionalism and the legal services market. International Journal of the Legal Profession 3, $137-168$.

Raine JW and Willson MJ (1997) Beyond managerialism in criminal justice. The Howard Journal 36, 80-95.

Schott C, Van Kleef D and Noordegraaf M (2016) Confused professionals? Capacities to cope with pressures on professional work. Public Management Review 18, 1-28.

Sommerlad H (1995) Managerialism, and the legal profession: a new professional paradigm. International Journal of the Legal Profession 2, 159-186.

Sommerlad H et al. (Forthcoming) Casualisation and proletarianisation. In Abel RL and Sommerlad H, with Hammerslev O and Schultz U (eds), Lawyers in $21^{\text {st }}$ Century Societies: Comparative Theories. Bloomsbury: Hart Publishing.

Spigelman JJ (2001) The 'New Public Management' and the courts. Australian Law Journal 75, 748-760.

Susskind R (2017) Tomorrow's Lawyers: An Introduction to Your Future, 2nd edn. Oxford: Oxford University Press.

Van de Bunt HG (1985) Officieren van justitie: verslag van een participerend observatieonderzoek. Zwolle: Tjeenk Willink.

Van de Bunt HG and Van Gelder JL (2012) The Dutch prosecution service. Crime and Justice 41, 117-140.

Van der Torre A et al. (2007) Rechtspraak: Productiviteit in perspectief. Den Haag: Sociaal en Cultureel Planbureau/de Rechtspraak.

Van Oorschot I (2014) Seeing the case clearly: file-work, material mediation, and visualizing practices in a Dutch criminal court. Symbolic Interaction 37, 439-457.

Vigour C (2006) Justice: l'introduction d'une rationalité managériale comme euphémisation des enjeux politiques. Droit et société 63-64, 425-455.

Vigour C (2015) Professions in policy and knowledge transfer: adaptations of lean management, and jurisdictional conflict in a reform of the French public service. International Journal of Sociology 45, 112-132.

Visser M, Schouteten R and Dikkers J (2019) Controlling the courts: New Public Management and the Dutch judiciary. Justice System Journal 40, 39-53.

Zouridis S (2016) From justice archipelago to security and justice chain: strategy-organisation configurations in the Dutch criminal justice system. In Hondeghem A, Rousseaux X and Schoenaers F (eds), Modernisation of the Criminal Justice Chain and the Judicial System: New Insights on Trust, Cooperation and Human Capital. Cham: Springer International Publishing, pp. 79-93.

Cite this article: Holvast NL, Lindeman JMW (2020). An inquiry into the blurring boundaries between professionals and paraprofessionals in Dutch courts and the public prosecution service. International Journal of Law in Context $\mathbf{1 6}$ 371-389. https://doi.org/10.1017/S1744552320000270 